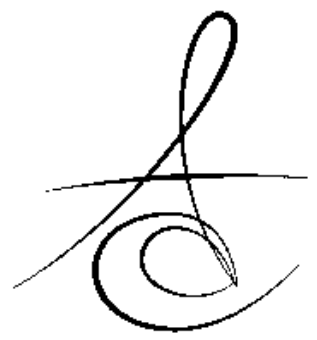

\title{
YEDİTEPE ÜNİVERSİTESİ DİŞHEKİMLİĞİ FAKÜLTESİ ÖĞRENCİLERİNDE AĞIZ-DİŞ SAĞLIĞI TUTUM VE DAVRANIŞLARININ DEĞERLENDİRİLMESI
}

\author{
YEDİTEPE UNIVERSITY FACULTY OF DENTISTRY ORAL HEALTH \\ STUDENTS EVALUATION OF ATTITUDE AND BEHAVIOR
}

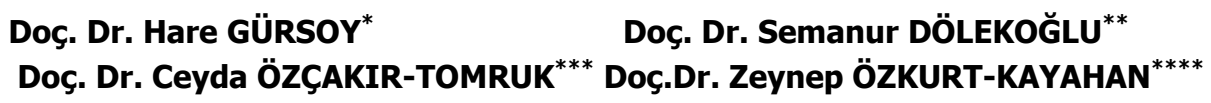

Makale Kodu/Article code: 2323

Makale Gönderilme tarihi: 22.06.2015

Kabul Tarihi: 24.12.2015

\section{öz}

Amaç: Bu çalışmanın amacı Yeditepe Üniversitesi Diş Hekimliği Fakültesinde öğrenim gören öğrencilerin ağız diş sağlığı tutum ve davranışlarını incelemektir.

Gereç ve Yöntem: Çalışmaya Yeditepe Üniversitesi Diş Hekimliği Fakültesi I, II, III, IV ve V. sınıflarında öğrenim gören 159 kı, 91erkek olmak üzere toplam 250 öğrenci dahil edildi. Öğrencilere, ağız diş sağığı tutum ve davranışlarını değerlendirmek amacıyla toplam 15 sorudan oluşan anket uygulandı.

Bulgular: Yapılan anket sonucunda anne ve babalarının eğitim düzeyi ile çocuklarının diş fırçalamaya başlama yaşları arasında istatistiksel olarak anlamılılı tespit edildi.

Sonuç: Çalışmamızın sonuçları, diş hekimliği eğitiminin bu eğitimi alan kişilerde ağız diş sağlığını tutum ve davranışlarını olumlu yönde etkilediğini göster- mektedir.

Anahtar kelimeler: Ağız ve diş sağlığı, diş öğrenciler

\section{GİRİŞ}

Ağız sağlığını korumak, var olan hastalığı durdurmak, sağlığı yeniden kazanmak ve kazanılan sağıı̆ın devamlılığında en önemli etken, düzenli, yeterli ve doğru bir ağız bakımı gerçekleştirmektir. Ağız bakımı denilince diş fırçası ve diş macununun yanında diş ipi ya da diş arası fırçası gibi arayüz ajanları ve diğer ağız bakım araçlarının da kullanımı akla gelmektedir ${ }^{1}$. Ağız bakımı konusunda yapılmış olan çalışmalara bakıldığında düzenli ve yeterli bir ağız bakımı için en azından

\section{ABSTRACT}

Aim: The purpose of the study is to evaluate the oral and dental care attitudes of students enrolled in Yeditepe University, Faculty of Dentistry.

Material and Methods: Two hundred and fifty students of the faculty in the 1st until the 5th years of education were included in the study of which 159 were females and 91 were males. The students were asked to fill out a survey form consisting of 15 questions in order to evaluate oral and dental healthcare attitudes.

Results: The results indicated that a statistical significance existed between the education level of parents and the age of initiation of tooth brushing.

Conclusion: It can be concluded that dental education has a positive impact on oral and dental healthcare attitudes on individuals involved in it.

Key words: oral and dental health, dental students

günde 2 kez dişlerin fırçalanması ve günde 1 kez diş aralarının diş ipi ile temizlenmesi gerektiği vurgulanmaktadır. ${ }^{1-3}$

Ağız sağlığı için doğru, düzenli ve yeterli bir ağız bakımı kadar bunun öncesinde kişinin ağız sağlığı ve bakımı hakkındaki bilgilerinin de doğru olması çok önemlidir ${ }^{1}$. Konuyla ilgili yapılan literatür incelemesinde diş çürükleri ve periodontal hastalıkların ne olduğu, primer sebepleri, klinik belirtileri ve hastalıkları önlemenin yolları ile ilgili soruları içeren az sayıda çalışmaya rastlanmakta ve Türkiye'de bu konuda yapılmış olan çalışmanın bulunmaması dikkat

*Yeditepe Üniversitesi Diş Hekimliği Fakültesi Periodontoloji AD

**Yeditepe Üniversitesi Diş Hekimliği Fakültesi Ağız Diş Çene Radyoloji AD

***Yeditepe Üniversitesi Diş Hekimliği Fakültesi Ağız, Diş, Çene Hastalıkları ve Cerrahisi AD

$* * * *$ Yeditepe Üniversitesi Diş Hekimliği Fakültesi Protetik Diş Tedavisi AD 
Atatürk Üniv. Diş Hek. Fak. Derg.

J Dent Fac Atatürk Uni

Cilt:26, Sayı:1, Yıl: 2016, Sayfa: 1-7
GÜRSOY, DÖLEKOĞLU, ÖZÇAKIR-TOMRUK ÖZKURT-KAYAHAN çekmektedir ${ }^{1}$. Diş çürüğü ve periodontal hastalıklar çeşitli sosyodemografik, lokal kazanılmış önlenebilir risk faktörleri, sistemik hastalıklar ve genetik faktörler tarafından modifiye edilmektedir ${ }^{4-10}$.

Çocuklar her konuda olduğu gibi ağız diş sağlığı konusunda da anne ve babalarını yansıtırlar ${ }^{1}$. Çocuklar diş fırçalamaya anne ve babalarını model alarak başlarlar. Bu model zaman içinde başta aile olmak üzere eğitim öğretimin tüm kademelerinde ve tüm yaşamları boyunca verilecek bilgilerle bilinçli bir alışkanlık halini alır ve sonraki nesillere aktarıır. Literatürde bu konuda yapılan çalışmalarda anne ve babaların, çocukların ağız bakımı üzerinde etkili oldukları gösterilmiştir ${ }^{1,11-13}$.

Bu çalışmanın amacı, diş hekimliği fakültesinde öğrenim gören kişilerin ağız diş sağlığı tutum ve davranışlarını incelemek ve anne ve babalarının eğitim düzeylerinin bu konu üzerinde olan etkilerini araştırmaktır.

\section{MATERYAL \& METOD}

Çalışmamıza, 10.03.2011-30.03.2011 tarihleri arasında, Yeditepe Üniversitesi Dişhekimliği Fakültesi'nde öğrenim gören, yaşları 18-25 arasında değişen, 159 kız 91 erkek olmak üzere toplam 250 öğrenci dahil edildi. Öğrencilere ağız diş sağlığı davranışlarını belirlemek adına toplam 15 sorudan oluşan anket uygulandı. $^{22}$ Sonuçlar, NCSS 2007\&PASS 2008 Statistical Software (Utah, USA) programı kullanılarak incelendi ve istatistiksel olarak anlamlılık $p<0.05$ düzeyinde de/ ğerlendirildi. Çalışma verileri değerlendirilirken tanımlayıcı istatistiksel metodların (ortalama, standart sapma, frekans) yanı sıra niteliksel verilerin karşılaştırılmasında Ki-Kare testi kullanıldı.

\section{BULGULAR}

159 'u $(\% 63,6)$ kız ve 91'i $(\% 36,4)$ erkek olan araştırma grubunun yaş ortalaması $21.29 \pm 1.64$ 'tür. Öğrencilerin 52'si $(\% 20,8)$ I. sınıf, 46'sı $(\% 18,4)$ II. sınıf, 68'i $(\% 27,2)$ III. sınıf, 41'i $(\% 16,4)$ IV. sınıf ve 43 ü $(\% 17,2)$ V. Sınıf öğrencisidir. Araştırma grubunun demografik özelliklerinin dağıımı Tablo 1'de gösterilmektedir. Buna göre; çalışmaya katılan öğrencilerin \%7,2'sinin babası ilkokul mezunu iken, \%20'sinin ortaokul, \%46,4'ünün lise ve \%26,4'ünün üniversite mezunudur. Çalışmaya katılan öğrencilerin \%12.8'inin annesi ilkokul mezunu iken, \%29,6'sının ortaokul, $\% 46,4$ 'ünün lise ve \%11,2'si üniversite mezunudur. Öğrencilerin \%47,6'sı ailesi ile birlikte yaşıyorken, $\% 35,2$ 'si tek veya arkadaşı ile birlikte, \%17,2'si ise yurtta kalmaktadır (Tablo 1).

Tablo 1. Demografik özelliklerin dağııııı

\begin{tabular}{llll}
\hline & & $\mathbf{n}$ & \% \\
\hline \hline \multirow{2}{*}{ Babanın } & İlkokul & 18 & 7,2 \\
Eğitim & Ortaokul & 50 & 20,0 \\
Durumu & Lise & 116 & 46,4 \\
& Üniversite & 66 & 26,4 \\
\hline \multirow{2}{*}{ Annenin } & İlkokul & 32 & 12,8 \\
Eğitim & Ortaokul & 74 & 29,6 \\
Durumu & Lise & 116 & 46,4 \\
& Üniversite & 28 & 11,2 \\
\hline \multirow{2}{*}{ Kaldığı } & Ailesi ile birlikte & 119 & 47,6 \\
Yer & Tek/ & 88 & 35,2 \\
& arkadaşı ile birlikte & & \\
& Yurtta & 43 & 17,2 \\
\hline
\end{tabular}

Babanın eğitim düzeyi ile diş fırçalamaya başlama yaşı arasında istatistiksel olarak ileri düzeyde anlamlı bir ilişki bulunmaktadır $(p<0.01)$. Babası lise ve üniversite mezunu olan diş hekimliği öğrencilerinin 6 yaş öncesi diş fırçalamaya başlamış olma oranları, babası ilkokul ve ortaokul mezunu olan öğrencilerden anlamlı şekilde yüksektir. Babanın eğitim düzeyi ile diş fırçalamayı öğreten kişi arasında istatistiksel olarak anlamlı bir ilişki bulunmamaktadır ( $p>0.05$ ) (Tablo 3). Öğrencilerin büyük bir kısmı diş fırçalamayı ebeveynlerinden öğrenmiştir (Tablo 2). Babanın eğitim düzeyi ile öğrencilerin diş hekimine gitme sıklıkları arasında istatistiksel olarak anlamlı bir ilişki bulunmamaktadır ( $p>0.05)$. Babanın eğitim düzeyi ile öğrencilerin diş fırçalama sıklıkları arasında istatistiksel olarak anlamlı bir ilişki bulunmamaktadır ( $p>0.05)$ (Tablo 3). Öğrencilerin büyük bir kısmının dişlerini günde iki-üç kez fırçaladıkları görülmektedir (Tablo 2).

Babanın eğitim düzeyine göre öğrencilerin diş fırçası dışında ara yüz temizleyicisi kullanma oranları arasında istatistiksel olarak anlamlı bir farklılık bulunmamaktadır ( $p>0.05$ ) (Tablo 3). Öğrencilerin büyük bir kısmının ara yüz temizleyicisi olarak diş ipi kullandıkları görülmektedir. Babanın eğitim düzeyine göre öğrencilerin diş fırçalamayı takiben ağız gargarası kullanma oranları arasında istatistiksel olarak anlamlı bir farklılık bulunmamaktadır ( $p>0.05)$. Öğrencilerin genellikle diş fırçaladıktan sonra ağız gargarası kullanmadıkları görülmektedir (Tablo 2). 
Atatürk Üniv. Diş Hek. Fak. Derg.

J Dent Fac Atatürk Uni

Cilt:26, Sayı:1, Yıl: 2016, Sayfa: 1-7
GÜRSOY, DÖLEKOĞLU, ÖZÇAKIR-TOMRUK ÖZKURT-KAYAHAN
Tablo 2. Sorulara verilen cevapların dağııımı

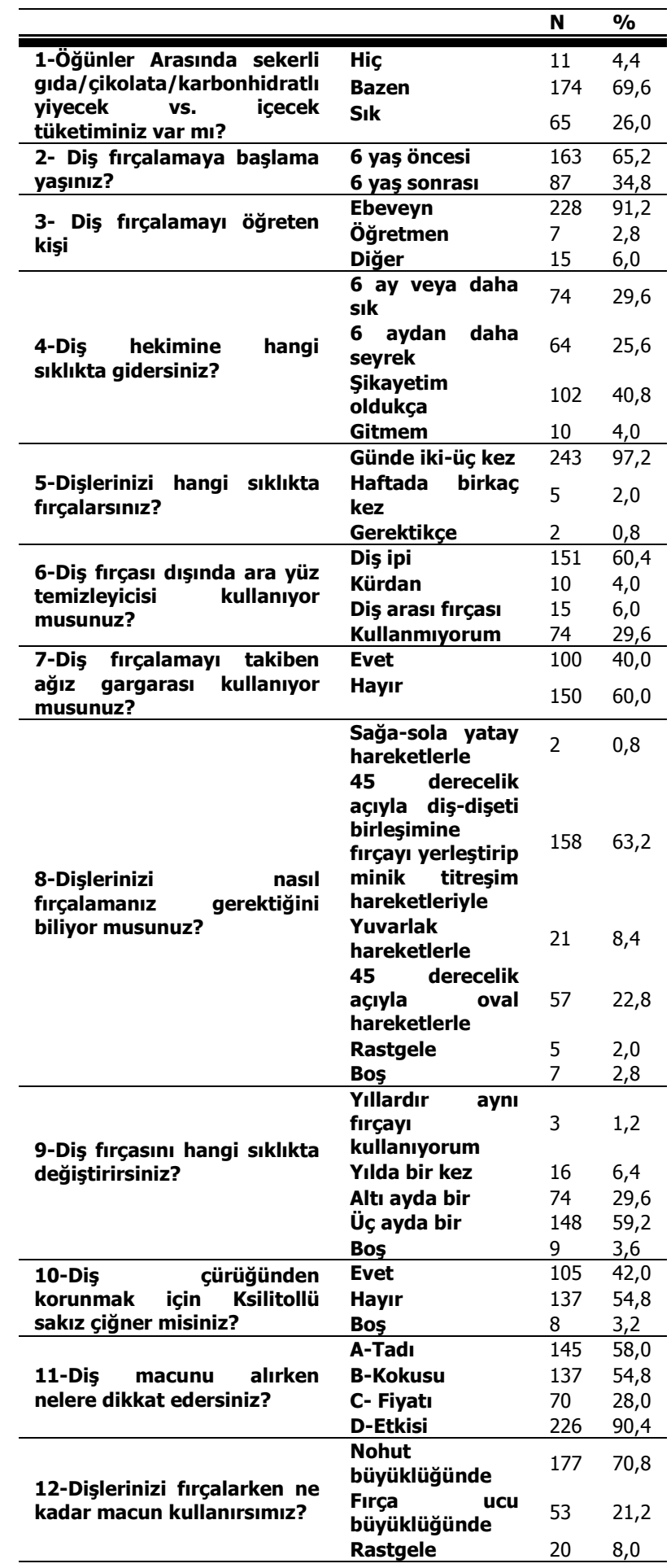

Babanın eğitim düzeyi ile öğrencilerin diş fırçalamayı bilmeleri arasında istatistiksel olarak anlamlı bir ilişki bulunmamaktadır ( $p>0.05$ ) (Tablo 3). Öğrencilerin genellikle 45 derecelik açıyla diş-diş eti birleşimine fırçayı yerleştirip minik titreşim hareketleriyle dişlerini fırçaladıkları görülmektedir (Tablo 2). Babanın eğitim düzeyine göre öğrencilerin diş fırçalarını değiştirme sıklıkları arasında istatistiksel olarak anlamlı bir farklılık bulunmamaktadır $(p>0.05)$. Öğrenciler genellikle diş fırçalarını üç ayda bir değiştirmektedirler. Babanın eğitim düzeyi ile diş çürüğünden korunmak için ksilitollü sakız çiğneme arasında istatistiksel olarak anlamlı bir ilişki bulunmaktadır $(\mathrm{p}<0.05)$ (Tablo 3). Babası lise ve üniversite mezunu olan diş hekimliği öğrencilerinin diş çürüğünden korunmak için ksilitollü sakız çiğneme oranları, babası ilkokul ve ortaokul mezunu olan öğrencilerden anlamlı şekilde yüksektir. Babanın eğitim düzeyine göre öğrencilerin diş macunu alırken tadına dikkat etme oranları arasında istatistiksel olarak anlamlı bir farklılık bulunmamaktadır ( $p>0.05$ ) (Tablo 3). Babanın eğitim düzeyine göre öğrencilerin diş macunu alırken kokusuna dikkat etme oranları arasında istatistiksel olarak anlamlı bir farklılık bulunmamaktadır ( $p>0.05$ ) (Tablo 3).

Babanın eğitim düzeyine göre öğrencilerin diş macunu alırken fiyatına dikkat etme oranları arasında istatistiksel olarak ileri düzeyde anlamlı farklıık bulunmaktadır ( $p<0.01$ ) (Tablo 3). Babası ortaokul mezunu olan öğrencilerin diş macunu alırken fiyatına dikkat etme oranları anlamlı şekilde yüksektir. Babanın eğitim düzeyine göre öğrencilerin diş macunu alırken etkisine dikkat etme oranları arasında istatistiksel olarak anlamlı bir farklılık bulunmamaktadır $(p>0.05)$ (Tablo 3). Babanın eğitim düzeyi ile öğrencilerin diş fırçalarken kullandıkları macun miktarları arasında istatistiksel olarak anlamlı bir farklılık bulunmamaktadır ( $p>0.05$ ). Öğrenciler genellikle diş fırçalarken nohut büyüklüğünde diş macunu kullanmaktadırlar (Tablo 2).

Annenin eğitim düzeyi ile diş fırçalamaya başlama yaşı arasında istatistiksel olarak ileri düzeyde anlamlı bir ilişki bulunmaktadır $(p<0.01)$ (Tablo 4). Annesi ortaokul, lise ve üniversite mezunu olan diş hekimliği öğrencilerinin 6 yaş öncesi diş fırçalamaya başlamış olma oranları, annesi ilkokul mezunu olan öğrencilerden anlamlı şekilde yüksektir. Annenin eğitim düzeyi ile diş fırçalamayı öğreten kişi arasında istatistiksel olarak anlamlı bir ilişki bulunmamaktadır ( $p>0.05)$. Annenin eğitim düzeyi ile öğrencilerin diş hekimine gitme sıklıkları arasında istatistiksel olarak anlamlı bir ilişki bulunmamaktadır ( $p>0.05)$. Annenin eğitim düzeyi ile öğrencilerin diş fırçalama sıklıkları arasında istatistiksel olarak anlamlı bir ilişki bulunma-

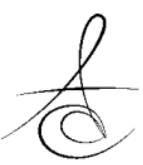


Atatürk Üniv. Diş Hek. Fak. Derg.

J Dent Fac Atatürk Uni

Cilt:26, Sayı:1, Yıl: 2016, Sayfa: 1-7
GÜRSOY, DÖLEKOĞLU, ÖZÇAKIR-TOMRUK ÖZKURT-KAYAHAN

Tablo 3. Babanın eğitim düzeyine ilişkin değerlendirmeler

\begin{tabular}{|c|c|c|c|c|c|c|}
\hline & & \multicolumn{4}{|c|}{ Babanın Eğitim Düzeyi } & \multirow{3}{*}{$p$} \\
\hline & & İlkokul & Ortaokul & Lise & Üniversite & \\
\hline & & n (\%) & n(\%) & n (\%) & n (\%) & \\
\hline \multirow{2}{*}{$\begin{array}{l}\text { Diş fırçalamaya başlama } \\
\text { yaşınız? }\end{array}$} & 6 yaş öncesi & $8(\% 44,4)$ & $26(\% 52,0)$ & $77(\% 66,4)$ & $52(\% 78,8)$ & \multirow{2}{*}{$0,005 * *$} \\
\hline & 6 yaş sonrası & $10(\% 55,6)$ & $24(\% 48,0)$ & $39(\% 33,6)$ & $14(\% 21,2)$ & \\
\hline \multirow{3}{*}{$\begin{array}{l}\text { Diş fırçalamayı öğreten } \\
\text { kişi }\end{array}$} & Ebeveyn & $14(\% 77,8)$ & $44(\% 88,0)$ & $109(\% 94,0)$ & $61(\% 92,4)$ & \multirow{3}{*}{0,182} \\
\hline & Öğretmen & $2(\% 11,1)$ & $1(\% 2,0)$ & $3(\% 2,6)$ & $1(\% 1,5)$ & \\
\hline & Diğer & $2(\% 11,1)$ & $5(\% 10,0)$ & $4(\% 3,4)$ & $4(\% 6,1)$ & \\
\hline \multirow{4}{*}{$\begin{array}{l}\text { Diş hekimine hangi } \\
\text { sıklıkta gidersiniz? }\end{array}$} & 6 ay veya daha sık & $2(\% 11,1)$ & $9(\% 18,0)$ & $42(\% 36,2)$ & $21(\% 31,8)$ & \multirow{4}{*}{0,154} \\
\hline & 6 aydan daha seyrek & $4(\% 22,2)$ & $16(\% 32,0)$ & $26(\% 22,4)$ & $18(\% 27,3)$ & \\
\hline & Şikayetim oldukça & $12(\% 66,7)$ & $23(\% 46,0)$ & $44(\% 37,9)$ & $23(\% 34,8)$ & \\
\hline & Gitmem & $0(\% 0)$ & $2(\% 4,0)$ & $4(\% 3,4)$ & $4(\% 6,1)$ & \\
\hline \multirow{3}{*}{$\begin{array}{l}\text { Dişlerinizi hangi sıklıkta } \\
\text { fırçalarsınız? }\end{array}$} & Günde iki-üç kez & $18(\% 100)$ & $49(\% 98,0)$ & $112(\% 96,6)$ & $64(\% 97,0)$ & \multirow{3}{*}{0,743} \\
\hline & Haftada birkaç kez & $0(\% 0)$ & $0(\% 0)$ & $3(\% 2,6)$ & $2(\% 3,0)$ & \\
\hline & Gerektikçe & $0(\% 0)$ & $1(\% 2,0)$ & $1(\% 0,9)$ & $0(\% 0)$ & \\
\hline \multirow{4}{*}{$\begin{array}{l}\text { Diş fırçası dışında ara yüz } \\
\text { temizleyicisi kullanıyor } \\
\text { musunuz? }\end{array}$} & Diş ipi & $9(\% 50,0)$ & $28(\% 56,0)$ & $71(\% 61,2)$ & $43(\% 65,2)$ & \multirow{4}{*}{0,397} \\
\hline & Kürdan & $1(\% 5,6)$ & $2(\% 4,0)$ & $7(\% 6,0)$ & $0(\% 0)$ & \\
\hline & Diş arası fırçası & $0(\% 0)$ & $5(\% 10,0)$ & $5(\% 4,3)$ & $5(\% 7,6)$ & \\
\hline & Kullanmıyorum & $8(\% 44,4)$ & $15(\% 30,0)$ & $33(\% 28,4)$ & $18(\% 27,3)$ & \\
\hline \multirow{2}{*}{$\begin{array}{l}\text { Diş fırçalamayı takiben } \\
\text { ağız gargarası kullanıyor } \\
\text { musunuz? }\end{array}$} & Evet & $5(\% 27,8)$ & $24(\% 48,0)$ & $40(\% 34,5)$ & $31(\% 47,0)$ & \multirow[b]{2}{*}{0,154} \\
\hline & Hayır & $13(\% 72,2)$ & $26(\% 52,0)$ & $76(\% 65,5)$ & $35(\% 53,0)$ & \\
\hline \multirow{5}{*}{$\begin{array}{l}\text { Dişlerinizi } \quad \text { nasıl } \\
\text { fırçalamanız gerektiğini } \\
\text { biliyor musunuz? }\end{array}$} & $\begin{array}{ll}\begin{array}{l}\text { Sağa-sola } \\
\text { hareketlerle }\end{array} & \text { yatay }\end{array}$ & $0(\% 0)$ & $0(\% 0)$ & $1(\% 0,9)$ & $1(\% 1,5)$ & \multirow{5}{*}{0,606} \\
\hline & $\begin{array}{l}45 \text { derecelik açıyla } \\
\text { minik } \\
\text { hareketleriyle }\end{array}$ & $15(\% 83,3)$ & $32(\% 65,3)$ & $74(\% 66,7)$ & $37(\% 56,9)$ & \\
\hline & Yuvarlak hareketlerle & $1(\% 5,6)$ & $5(\% 10,2)$ & $11(\% 9,9)$ & $4(\% 6,2)$ & \\
\hline & $\begin{array}{l}45 \text { derecelik açıyla oval } \\
\text { hareketlerle }\end{array}$ & $2(\% 11,1)$ & $12(\% 24,5)$ & $23(\% 20,7)$ & $20(\% 30,8)$ & \\
\hline & Rastgele & $0(\% 0)$ & $0(\% 0)$ & $2(\% 1,8)$ & $3(\% 4,6)$ & \\
\hline \multirow{4}{*}{$\begin{array}{l}\text { Diş fırçasını hangi sıklıkta } \\
\text { değiştirirsiniz? }\end{array}$} & Yıllardır aynı fırça & $0(\% 0)$ & $1(\% 2,0)$ & $1(\% 0,9)$ & $1(\% 1,6)$ & \multirow{4}{*}{0,856} \\
\hline & Yılda bir kez & $1(\% 5,6)$ & $4(\% 8,2)$ & $6(\% 5,4)$ & $5(\% 7,9)$ & \\
\hline & Altı ayda bir & $5(\% 27,8)$ & $13(\% 26,5)$ & $41(\% 36,9)$ & $15(\% 23,8)$ & \\
\hline & Üç ayda bir & $12(\% 66,7)$ & $31(\% 63,3)$ & $63(\% 56,8)$ & $42(\% 66,7)$ & \\
\hline \multirow{2}{*}{$\begin{array}{l}\text { Diş çürüğünden } \\
\text { korunmak için Ksilitollü } \\
\text { sakız çiğner misiniz? }\end{array}$} & Evet & $5(\% 27,8)$ & $13(\% 26,5)$ & $56(\% 50,9)$ & $31(\% 47,7)$ & \multirow{2}{*}{$0,015^{*}$} \\
\hline & Hayır & $13(\% 72,2)$ & $36(\% 73,5)$ & $54(\% 49,1)$ & $34(\% 52,3)$ & \\
\hline \multirow{4}{*}{$\begin{array}{l}\text { Diş macunu alırken nelere } \\
\text { dikkat edersiniz? }\end{array}$} & A-Tadı & $10(\% 66,7)$ & $27(\% 71,1)$ & $72(\% 74,2)$ & $36(\% 62,1)$ & \multirow{4}{*}{$\begin{array}{l}0,451 \\
0,504 \\
0,001 * * \\
0,175\end{array}$} \\
\hline & B-Kokusu & $11(\% 78,6)$ & $25(\% 69,4)$ & $67(\% 73,6)$ & $34(\% 63,0)$ & \\
\hline & C- Fiyatı & $7(\% 46,7)$ & $23(\% 60,5)$ & $29(\% 33,7)$ & $11(\% 20,8)$ & \\
\hline & D-Etkisi & $18(\% 100)$ & $45(\% 93,8)$ & $100(\% 94,3)$ & $63(\% 100)$ & \\
\hline \multirow{3}{*}{$\begin{array}{l}\text { Dişlerinizi fırçalarken ne } \\
\text { kadar macun } \\
\text { kullanırsımız? }\end{array}$} & Nohut büyüklüğünde & $12(\% 66,7)$ & $38(\% 76,0)$ & $80(\% 69,0)$ & $47(\% 71,2)$ & \multirow{3}{*}{0,855} \\
\hline & Fırça ucu büyüklüğünde & $4(\% 22,2)$ & $7(\% 14,0)$ & $27(\% 23,3)$ & $15(\% 22,7)$ & \\
\hline & Rastgele & $2(\% 11,1)$ & $5(\% 10,0)$ & $9(\% 7,8)$ & $4(\% 6,1)$ & \\
\hline
\end{tabular}


Tablo 4. Annenin eğitim düzeyine ilişkin değerlendirmeler

\begin{tabular}{|c|c|c|c|c|c|c|}
\hline & & \multicolumn{4}{|c|}{ Annenin Eğitim Düzeyi } & \multirow[b]{2}{*}{$p$} \\
\hline & & $\begin{array}{c}\text { İlkokul } \\
\text { n (\%) } \\
\end{array}$ & $\begin{array}{l}\text { Ortaokul } \\
\text { n (\%) } \\
\end{array}$ & $\begin{array}{c}\text { Lise } \\
\text { n (\%) } \\
\end{array}$ & $\begin{array}{c}\text { Üniversite } \\
\text { n (\%) } \\
\end{array}$ & \\
\hline $\begin{array}{l}\text { Diş fırçalamaya başlama } \\
\text { yaşınız? }\end{array}$ & $\begin{array}{l}6 \text { yaş öncesi } \\
6 \text { yaş sonrası }\end{array}$ & $\begin{array}{l}12(\% 37,5) \\
20(\% 62,5)\end{array}$ & $\begin{array}{l}45(\% 60,8) \\
29(\% 39,2) \\
\end{array}$ & $\begin{array}{l}82(\% 70,7) \\
34(\% 29,3)\end{array}$ & $\begin{array}{c}24(\% 85,7) \\
4(\% 14,3) \\
\end{array}$ & $0,001 * *$ \\
\hline $\begin{array}{l}\text { Diş fırçalamayı öğreten } \\
\text { kişi }\end{array}$ & $\begin{array}{l}\text { Ebeveyn } \\
\text { Öğretmen } \\
\text { Diğer }\end{array}$ & $\begin{array}{c}29(\% 90,6) \\
2(\% 6,3) \\
1(\% 3,1)\end{array}$ & $\begin{array}{c}65(\% 87,8) \\
1(\% 1,4) \\
8(\% 10,8)\end{array}$ & $\begin{array}{c}107(\% 92,2) \\
3(\% 2,6) \\
6(\% 5,2)\end{array}$ & $\begin{array}{c}27(\% 96,4) \\
1(\% 3,6) \\
0(\% 0)\end{array}$ & 0,295 \\
\hline $\begin{array}{l}\text { Diş hekimine hangi } \\
\text { sıklıkta gidersiniz? }\end{array}$ & $\begin{array}{l}6 \text { ay veya daha sık } \\
6 \text { aydan daha seyrek } \\
\text { Şikayetim oldukça } \\
\text { Gitmem }\end{array}$ & $\begin{array}{c}6(\% 18,8) \\
8(\% 25,0) \\
17(\% 53,1) \\
1(\% 3,1) \\
\end{array}$ & $\begin{array}{c}18(\% 24,3) \\
24(\% 32,4) \\
30(\% 40,5) \\
2(\% 2,7) \\
\end{array}$ & $\begin{array}{c}43(\% 37,1) \\
23(\% 19,8) \\
46(\% 39,7) \\
4(\% 3,4) \\
\end{array}$ & $\begin{array}{l}7(\% 25,0) \\
9(\% 32,1) \\
9(\% 32,1) \\
3(\% 10,7) \\
\end{array}$ & 0,160 \\
\hline $\begin{array}{l}\text { Dişlerinizi hangi sıklıkta } \\
\text { fırçalarsınız? }\end{array}$ & $\begin{array}{l}\text { Günde iki-üç kez } \\
\text { Haftada birkaç kez } \\
\text { Gerektikçe }\end{array}$ & $\begin{array}{c}31(\% 96,9) \\
0(\% 0) \\
1(\% 3,1)\end{array}$ & $\begin{array}{c}74(\% 100) \\
0(\% 0) \\
0(\% 0)\end{array}$ & $\begin{array}{c}112(\% 96,6) \\
3(\% 2,6) \\
1(\% 0,9)\end{array}$ & $\begin{array}{c}26(\% 92,9) \\
2(\% 7,1) \\
0(\% 0)\end{array}$ & 0,167 \\
\hline $\begin{array}{l}\text { Diş fırçası dışında ara yüz } \\
\text { temizleyicisi kullanıyor } \\
\text { musunuz? }\end{array}$ & $\begin{array}{l}\text { Diş ipi } \\
\text { Kürdan } \\
\text { Diş arası fırçası } \\
\text { Kullanmıyorum } \\
\end{array}$ & $\begin{array}{c}17(\% 53,1) \\
1(\% 3,1) \\
3(\% 9,4) \\
11(\% 34,4) \\
\end{array}$ & $\begin{array}{c}50(\% 67,6) \\
2(\% 2,7) \\
4(\% 5,4) \\
18(\% 24,3) \\
\end{array}$ & $\begin{array}{c}68(\% 58,6) \\
7(\% 6,0) \\
7(\% 6,0) \\
34(\% 29,3) \\
\end{array}$ & $\begin{array}{c}16(\% 57,1) \\
0(\% 0) \\
1(\% 3,6) \\
11(\% 39,3)\end{array}$ & 0,692 \\
\hline $\begin{array}{l}\text { Diş fırçalamayı takiben } \\
\text { ağız gargarası kullanıyor } \\
\text { musunuz? }\end{array}$ & $\begin{array}{l}\text { Evet } \\
\text { Hayır }\end{array}$ & $\begin{array}{l}11(\% 34,4) \\
21(\% 65,6)\end{array}$ & $\begin{array}{l}33(\% 44,6) \\
41(\% 55,4)\end{array}$ & $\begin{array}{l}46(\% 39,7) \\
70(\% 60,3)\end{array}$ & $\begin{array}{l}10(\% 35,7) \\
18(\% 64,3) \\
\end{array}$ & 0,731 \\
\hline \multirow[t]{3}{*}{$\begin{array}{l}\text { Dişlerinizi nasıl } \\
\text { fırçalamanız gerektiğini } \\
\text { biliyor musunuz? }\end{array}$} & $\begin{array}{l}\text { Sağa-sola yatay } \\
\text { hareketlerle } \\
45 \text { derecelik açıyla } \\
\text { minik titreşim } \\
\text { hareketleriyle } \\
\text { Yuvarlak hareketlerle }\end{array}$ & $\begin{array}{c}21(\% 65,6) \\
3(\% 9,4)\end{array}$ & $54(\% 76,1)$ & $68(\% 60,2)$ & $\begin{array}{c}15(\% 55,6) \\
1(\% 3,7)\end{array}$ & \multirow[t]{3}{*}{0,355} \\
\hline & $\begin{array}{l}45 \text { derecelik açıyla oval } \\
\text { hareketlerle }\end{array}$ & $8(\% 25,0)$ & $11(\% 15,5)$ & $28(\% 24,8)$ & $10(\% 37,0)$ & \\
\hline & Rastgele & $0(\% 0)$ & $0(\% 0)$ & $4(\% 3,5)$ & $1(\% 3,7)$ & \\
\hline $\begin{array}{l}\text { Diş fırçasını hangi sıklıkta } \\
\text { değiştirirsiniz? }\end{array}$ & $\begin{array}{l}\text { Yıllardır aynı fırça } \\
\text { Yılda bir kez } \\
\text { Altı ayda bir } \\
\text { Üç ayda bir }\end{array}$ & $\begin{array}{c}0(\% 0) \\
2(\% 6,3) \\
12(\% 37,5) \\
18(\% 56,3) \\
\end{array}$ & $\begin{array}{c}2(\% 2,9) \\
4(\% 5,7) \\
19(\% 27,1) \\
45(\% 64,3) \\
\end{array}$ & $\begin{array}{c}1(\% 0,9) \\
6(\% 5,3) \\
40(\% 35,4) \\
66(\% 58,4) \\
\end{array}$ & $\begin{array}{c}0(\% 0) \\
4(\% 15,4) \\
3(\% 11,5) \\
19(\% 73,1) \\
\end{array}$ & 0,252 \\
\hline $\begin{array}{l}\text { Diş çürüğünden } \\
\text { korunmak için Ksilitollü } \\
\text { sakız çiğner misiniz? }\end{array}$ & $\begin{array}{l}\text { Evet } \\
\text { Hayır }\end{array}$ & $\begin{array}{l}10(\% 31,3) \\
22(\% 68,7)\end{array}$ & $\begin{array}{l}27(\% 38,0) \\
44(\% 62,0)\end{array}$ & $\begin{array}{l}56(\% 49,6) \\
57(\% 50,4)\end{array}$ & $\begin{array}{l}12(\% 46,2) \\
14(\% 53,8)\end{array}$ & 0,205 \\
\hline $\begin{array}{l}\text { Diş macunu alırken } \\
\text { nelere dikkat edersiniz? }\end{array}$ & $\begin{array}{l}\text { A-Tadı } \\
\text { B-Kokusu } \\
\text { C- Fiyatı } \\
\text { D-Etkisi }\end{array}$ & $\begin{array}{l}19(\% 79,2) \\
17(\% 77,3) \\
10(\% 47,6) \\
30(\% 96,8)\end{array}$ & $\begin{array}{l}40(\% 63,5) \\
39(\% 66,1) \\
26(\% 42,6) \\
65(\% 97,0)\end{array}$ & $\begin{array}{l}71(\% 74,0) \\
63(\% 70,8) \\
30(\% 35,3) \\
105(\% 95,5)\end{array}$ & $\begin{array}{c}15(\% 60,0) \\
18(\% 72,0) \\
4(\% 16,0) \\
26(\% 96,3)\end{array}$ & $\begin{array}{l}0,250 \\
0,788 \\
0,082 \\
0,957\end{array}$ \\
\hline $\begin{array}{l}\text { Dişlerinizi fırçalarken ne } \\
\text { kadar macun } \\
\text { kullanırsımız? }\end{array}$ & $\begin{array}{l}\text { Nohut büyüklüğüünde } \\
\text { Fırça ucu } \\
\text { büyüklüğünde } \\
\text { Rastgele }\end{array}$ & $\begin{array}{c}26(\% 81,3) \\
4(\% 12,5) \\
2(\% 6,3)\end{array}$ & $\begin{array}{c}56(\% 75,7) \\
9(\% 12,2) \\
9(\% 12,2) \\
\end{array}$ & $\begin{array}{c}76(\% 65,5) \\
32(\% 27,6) \\
8(\% 6,9)\end{array}$ & $\begin{array}{c}19(\% 67,9) \\
8(\% 28,6) \\
1(\% 3,6)\end{array}$ & 0,096 \\
\hline
\end{tabular}

maktadır ( $p>0.05)$. Annenin eğitim düzeyine göre öğrencilerin diş fırçası dışında ara yüz temizleyicisi kullanma oranları arasında istatistiksel olarak anlamlı bir farklılık bulunmamaktadır ( $p>0.05$ ). Annenin eğitim düzeyine göre öğrencilerin diş fırçalamayı takiben ağız gargarası kullanma oranları arasında istatistiksel olarak anlamlı bir farklılık bulunmamaktadır ( $p>0.05)$. Annenin eğitim düzeyi ile öğrencilerin diş fırçalamayı bilmeleri arasında istatistiksel olarak anlamlı bir ilişki bulunmamaktadır ( $p>0.05)$. Annenin eğitim düzeyine göre öğrencilerin diş fırçalarını değiştirme sıklıkları arasında istatistiksel olarak anlamlı bir farklılık bulunmamaktadır ( $p>0.05)$. Annenin eğitim düzeyi ile diş çürüğünden korunmak için Ksilitollü sakız çiğneme arasında istatistiksel olarak anlamlı bir ilişki bulunmamaktadır ( $p>0.05)$. Annenin eğitim düzeyine göre öğrencilerin diş macunu alırken tadına dikkat etme oranları arasında istatistiksel olarak anlamlı bir farklılık bulunmamaktadır ( $p>0.05)$. Annenin eğitim düzeyine göre öğrencilerin diş macunu alırken kokusuna dikkat etme oranları arasında istatistiksel olarak anlamlı bir farklılık bulunmamaktadır ( $p>0.05$ ). Annenin eğitim düzeyine göre öğrencilerin diş macunu alırken fiyatına dikkat etme oranları arasında istatistiksel olarak anlamlı bir farklıık bulunmamaktadır $(p>0.05)$. Annenin eğitim düzeyine göre öğrencilerin diş macunu alırken etkisine dikkat etme oranları arasında istatis- 
Atatürk Üniv. Diş Hek. Fak. Derg.

J Dent Fac Atatürk Uni

Cilt:26, Sayı:1, Yıl: 2016, Sayfa: 1-7
GÜRSOY, DÖLEKOĞLU, ÖZÇAKIR-TOMRUK ÖZKURT-KAYAHAN tiksel olarak anlamlı bir farklılık bulunmamaktadır ( $p>0.05)$. Annenin eğitim düzeyi ile öğrencilerin diş fırçalarken kullandıkları macun miktarları arasında istatistiksel olarak anlamlı bir farklılık bulunmamaktadır ( $p>0.05)$.

\section{TARTIŞMA}

Toplumuzda hala ağız diş sağlığına gereken önem verilmemektedir 14, 15. Bir topluma koruyucu amaçlı bir program uygulanmak istendiğinde öncelikle toplum içindeki yüksek çürük riskine sahip birey veya grupların saptanması koruyucu programın başarısı açısından çok önemlidir ${ }^{14,15}$. Dünya Sağlık Örgütünün desteği ile 1988 yılında yapılan 'Türkiyedeki Ağız Diş Sağlığı Analizi Raporu' toplumun değişik bölümlerini içermesi ve farklı yaş gruplarını kapsaması bakımından önemli bir temel oluşturmaktadır ${ }^{14}$. Bu raporun sonuçlarına göre 6 yaş grubu çocuklarda çürüksüzlük oranı \%16 iken sürekli diş dizisi ağızda yer almış olarak kabul edilen 12 yaş grubunda \%19, 30-35 yaş grubunda ise \%3'tür ${ }^{14 .}$

Astrom ve Jakopsen ${ }^{16}$ yaptıkları çalışmada anne ve babalarının diş ipi, diş fırçası ve şekersiz maden suyu kullanımıyla çocuklarının da bunları kullanımı arasında istatistiksel olarak anlamlı bir ilişki bulmuşlardır. Bizim çalışmamızın bulguları da Astrom ve Jakopsen'in çalışma sonuçlarıyla uyumludur

Eccleston $^{17}$, Japonya'da sosyal ya da sınıf faklılıklarının çok az olduğunu bildirmiştir. Japon kültüründe sosyoekonomik varyasyon diğer ülkelerle kıyaslandığında çok daha azdır ve bu ülkede yaşayan tüm insanların medikal ve sosyal güvence altında oduğu rapor edilmiştir. Bütün şartlar sabit olduğunda, Japonya'da pek çok insanın diş ipi kullanımı konusunda bilgi sahibi olmadığı bildirilmiştir 18,19 . Japonya'da yapılan başka bir araştırmada sosyal değişkenlerin oral hijyen üzerine olan etkisi (günlük diş fırçası ve diş ipi kullanımıyla dental plağın uzaklaştırıması) ile ilgili yapılan araştırmaların sayısının çok az olmasına rağmen, çocukların büyüme gelişim dönemlerinde bu konuda cesaretlendirildiğinde kendi kendine günlük oral hijyen işlemlerini yapabileceği bildirilmiştir. Bu çalışmada anne ve babaların oral hijyene gösterdikleri önemin erkek çocukların ağızlarında görülen çürük dişler ve dişeti sağlıkları üzerinde direkt etkili olduğu bildirilirken, kız çocuklarında indirekt etkili olduğu bildirilmiştir ${ }^{11}$. Bizim çalışma bulgularımız da bu çalışmanın bulgularıyla uyumluluk göstermektedir.

Çebi ve ark.'nın çalışmalarında, diş hekimliği fakültesi öğrencilerinde fırçalama alışkanlıklarının daha düzenli ve fırçalama tekniğinin daha doğru olduğu bildirilmiştir. ${ }^{20}$ Yılmaz ve ark. ${ }^{21}$ yaptıkları çalışmada, sınıf yükseldikçe fırçalama alışkanlıklarının daha düzenli olduğu, fırçalama tekniklerinin ise daha doğru uygulandığı rapor edilmiştir. Danimarka'da yapılan başka bir araştırmada ise diş hekimliği öğrencilerinin sınıf sayısının yükselmesiyle ağız bakımının olumlu yönde etkilendiği bildirilmiştir. Arslan ve ark. ${ }^{22}$ yaptıkları çalışmada, sınıf sayısı arttıkça diş hekimine kontrole gidilmesinin, doğru fırçalama tekniği kullanımının, fırça dışında diğer dental hijyen ajanlarının ve doğru miktarda macun kullanım oranlarının arttığını tespit etmişlerdir. $\mathrm{Bu}$ çalışmaların bulguları bizim çalışmamızla uyumluluk göstermektedir.

\section{SONUÇ}

$\mathrm{Bu}$ çalışmanın sınırları dahilinde, diş hekimliği eğitiminin bu eğitimi alan kişilerin ağız diş sağlığı tutum ve davranışlarını olumlu yönde etkilediği, anne ve babalarının bu eğitimi vermede en önemli faktörlerin başında geldiği ve ebeveynlerin eğitim düzeylerinin ağız diş sağlığı tutum ve davranışlarını yönlendirdiği düşünülmektedir.

\section{KAYNAKLAR}

1- Demirer S., Çatalbaş B., Gelgör E., Görür T., Karşıyaka M. Ortodontik tedaviye başvuran çocuklar ve ebeveynlerinin ağız sağlığı bilinç düzeyleri, ağız bakımı ve ağız sağlığı durumlarının karşılaştırılması: Ön çalışma. S Ü Dişhek Fak Derg 2010; 19: 26-34.

2- Löe $\mathrm{H}$. Oral hygiene in the prevention of caries and periodontal disease. Int Dent J 2000; 50:129-39.

3- Lang N.P., Cumming B.R., Loe H. Toothbrushing frequency as it relates to plaque development and gingival health. J. Periodontol 1973; 44: 396-405.

4- Ağız ve diş sağlığı hizmetleri. http://www.saglik. gov.tr/TR/belgegoster.aspx?F6E10F8892433CFFAA F6AA849816B2EFFBFD747831067508:20.03.2009.

5- Ramfjford S.P., Ash M.M. Periodontology and periodontics.: Modern theory and practice. Ishiyaku EuroAmerica, Inc, St, Louis, Tokyo, 1989. 
6- Carranza F.A., Newman M.G., Clinical periodontology, Ed, Carranza F.A., Newman M.G., 8th edition, W,B, Saunders Co, Philedelphia, 2002.

7- Ataoglu T., Gürsel M. Periodontoloji, 2. baskı, Damla ofset, 1997.

8- Liebana J., Castillo A. Phsiopathology of primary periodontitis associated with olaque, Microbial and host factors, A review, Part 1. Aust Dent J 1994; 4:228-32.

9- Matthews D.C., Tabesh M.: Detection of localized tooth related factors that predispose to periodontal infections. Periodontol 2000 2004; 34:136-50.

10-Genco R.J., Factors for Periodontal Disease. Periodontal medicine. BC., Decker Inc, Hamilton 2000.

11-Okada, M. Kawamura Y., Kaıhara Y. Matsuzakı S. Kuwahara, $\mathrm{H}$. Ishidori $\mathrm{K}$. Mıura. Influence of parents' oral health behaviour on oral health status of their school children: an exploratory study employing a causal modelling technique. Int J Ped Dent 2002; 12: 101-8.

12-Tekir Ö, Çalışkan T.: Okul öncesi dönemdeki iki farklı grup için ağız diş sağlı̆ı uygulamalarında ebeveynin tutumunun karşılaştıııması. Fırat Sağlık Hizmetleri Derg 2007; 2: 111-22.

13-Efe E, Sarvan S, Kukulu K. Self reported knowledge and behaviours related to oral and dental health in Turkish children. Issues Compr Paediatr Nurs 2007; 30:133-46.

14-Saydam G, Oktay İ, Möller I.: Türkiye'de Ağız Diş Sağı̆ğı Durum Analizi. Tür-Ağız Sağ.001 (dsö) Seçil ofset. İstanbul, 1990.

15-Taşveren K., Sözean A., Yeler D., Taşveren S.: 12 Yaş Grubu Çocukların Diş Fırçalama Sıklığı-DMFT ilişkisi. Atatürk Üniv Diş Hek Fak 2005;15:11-4

16-Astrom A.N., Jakopsen R. The effect of parental dental health behaviour on that of their adolescent offspring. Acta Odontologica Scandinavica 1996; 54: 235-41.

17-Eccleston B. Social equality: the distrubution of income and wealth. In: State and society in post war Japan. Oxford: Blackwell publishing, 1993: 164-7.

18-Fukai K, Maki Y, Takaesu Y. Oral health behavior of adults in relation to age groups [in Japanese, English abstract]. Journal of Dental Health 1996; 46: 676-82.
19-Kawamura M, Iwamoto Y. Present state of dental health knowledge, attitudes/behaviour and perceived oral health of Japanese employees. Int Dent J 1999; 49: 173-81.

20-Çebi S, Dayangaç B, Demiröz T. Dişhekimliği Eğitiminin diş sağı̆ğına etkisi. Hacettepe Diş Hek Fak Derg 1978; 2: 211-22.

21-Yılmaz AB, Yanıkoğlu N, Ceylan G., Akgül M. Atatürk Üniversitesi Diş Hekimliği Fakültesi Öğrencilerinde ağız diş sağlı̆ı çalışması ve diş hekimliği eğitiminin ağız sağlığına olan etkisinin araştıııması. Atatürk Üniv Diş Hek Fak Derg 1997;7: 36-9.

22-Arslan $S$, Elamlı $F$, Ülker $M$, Öztürk $A$, Günay $O$. Dişhekimliği Fakültesi Öğrencilerinde Çürük Prevalansı, Ağız Diş Sağlığı Tutum ve Davranışları ve Dental Anksiyetenin Belirlenmesi. AÜ Diş Hek Fak Derg 2008;35: 53-60

\section{Yazışma Adresi:}

Doç. Dr. Hare Gürsoy

Yeditepe Üniversitesi Diş Hekimliği Fakültesi

Bağdat Caddesi No:238

Göztepe/İstanbul

Tel: 02163636044

Fax: 02163636211

E-mail: haregursoy@hotmail.com 